I refer to the power problem. In a country blessed beyond comparison with all the necessary natural resources for a large chemical industry, with a home consumption greater than that of any other country, with an enterprising population, with immense deposits of coal and other sources of fuel, navigable streams, railroads, and ever-increasing methods of land and water transportation, we, nevertheless, are very short of cheap water powers. Our great development of the electrochemical industries in the United States was due to the fact that for the first time we placed at the disposal of our industries abundant electrical current at lower rates than had been obtainable in the past by means of steam. We became the leaders in those industries. Niagara Falls and its industries became a by-word of electrochemical supremacy throughout the world. Some of the most epoch-making inventions in this branch of chemical industry were encouraged by this condition. Since then other countries have gone us one better in the production of cheap water power. Unless we change our present condition it looks as if our electrochemical industries, our leading chemical industries, were going to be wrested from us to find a more inviting home in Canada and in Norway. Unfortunately, here again the condition is one of "dog-in-the-manger" politics.

For purposes like electric lighting or traction, or most chemical industries, a few dollars more or less a year expressed in kilowatt-hours amounts to a mere trifle. But when it comes to making chemicals or metals at the very lowest possible cost, then every dollar counts, and here we are unfortunately face to face with the distressing fact that, with our present methods of financing, the fixed charges of our water powers amount to about 90 cents financing and to cents engineering. If engineers succeeded in increasing their efficiency of operation Io per cent, it would only amount to I per cent in the total cost. So, if any improvements have to be made, it must be in the financial side of the problem. Meanwhile everyone advances his own arguments why it should be this way, and everyone is more or less right-from his personal standpoint. Capitalists say: "Some of our Government laws about the utilization of our water powers are so uncertain and threatening that we prefer to invest in less risky enterprises." Then our rates of interest in this country are considerably higher than they are in Europe. Some other persons have proposed that the United States Government should use its own excellent credit and thus be able to issue bonds for water powers at low interest, in the same way as the Panama Canal has been constructed. With our wasteful methods of financing and banking, and the many middlemen, it costs usually about 9 per cent to accomplish this result by the time the bonds are floated and put in the hands of the hesitating investor. This puts the annual cost of some of our cheapest water powers at \$Io a horsepower-year, of which $\$ 9$ is for interest and bonded charges and \$I for general operation and maintenance expenses, to which has to be added profit for dividends. But with interest at 4 per cent the cost per horsepower would suddenly be reduced to $\$ 5$ to $\$ 7$ per horsepower-year, which brings it closer to that of some of the water-power developments in Norway. Then, again, others say that the Government has no right to participate in any such enterprise, or that it is unprepared and unfit for any such business operation. To this others retort that the erection and operation of a hydroelectric plant is much easier and less expensive for the Government than for private companies, because the Government has already in its power the question of extending the navigability of streams, which, by the way, has always been a never-ending source of "pork-barrel" appropriations. Streams are made navigable by the erection of dams. By the proper selection of stream and location the cost of the dam can be made to furnish the most important part of the total outlay for a hydroelectric plant; all that is necessary is to add the turbines and the electric equipment for obtaining at somewhat increased cost a first-class hydro- electric plant, furnishing forever electric current for any purposes. A hydroelectric plant as a Government enterprise would not involve much of a new departure as compared with that splendid example of good engineering, the Panama Canal, which is a rational monument of efficiency, and which, similar to the present problem, is an asset for national defense in time of war, while in the meantime it is an aid to private shipping enterprises. The methods of hydroelectric plants are, by this time, well established and well known, and leave little scope for further improvement except the enormous cheapening which is possible for such plants in the reduction of fixed charges by very economical financing.

These are some of the dark points on the horizon of our chemical industries. What will happen depends very much on whether in the future our legislators will look at everything from a political or a one-sided standpoint, or whether they shall have learned in earnest to utilize the advice of competent men, and put the welfare of the United States before sectionalism and personal political ambition.

\section{RUSSIA AND ITS RELATIONSHIPS TO THE UNITED STATES}

Abstract of ADdress by C. H. Boynton

President American-Russian Chamber of Commerce September 26, 1917

The speaker emphasized the unusual political conditions now in Russia and expressed the belief that the Russians would be able to straighten out the tangle themselves. He strongly emphasized the necessity for America forming its opinion of Russia from information and data furnished by Americans, especially the men in the American Diplomatic and Consular Service, and American business men in direct contact with Russian affairs.

Mr. Boynton enumerated many of the natural resources of Russia, whose territory covers two and a half times that of the United States, with a population of $180,000,000$, and a birth rate higher than that of any civilized nation: in the ten years between the Russo-Japanese and the present war, Russia had in many instances doubled the output of her raw materials and her natural wealth.

Russian Commissions are now studying manufacturing, mining, railroads, textiles and every branch of industry, and the methods and laws under which other countries have developed their resources. It is intended to re-draft entirely legal procedure, corporation law, mining law and almost every law which enters into economic development.

Mr. Boynton stated that he had yet to meet an American with sound business judgment, who had made a visit to Russia and personally investigated Russian affairs, who did not return enthusiastic over the future possibilities of Russia.

Russia offers an unlimited field for chemical development in all classes, in the beginning as an importer of American chemicals and later as a chemical producer.

$\mathrm{Mr}$. Boynton gave numbers of instances showing our political indebtedness to Russia, and the sentimental and practical reasons why we should assist her in maintaining her democracy and aid her in developing her resources.

\section{NATURAL RESOURCES SYMPOSIUM September 27, 1917 \\ AHOPPA AWAN TEWA (THE DEAD THEIR DAY)}

EXTracts From Address by C. H. CRAwFord

Assistant to President, Nashville, Chattanooga and St. Louis Railway

It might be wondered why a concern with but one product to sell, which, strictly speaking, is not competitive but is an essential - the absolute basis-of all industrial products, Transportation, should take the trouble, expend the money and use 
up the time of part of its personnel to attend an exposition of this kind, but if you will look over the exhibit you will find that several railroads have done this. What is the reason?

All railroads have at least two kinds of industries - those that "just grow" and those that are planted. There seems to me to be a middle ground, largely uninhabited, in matters of this kind which is much better for all concerned.

I do not believe that there is any business organization that realizes Preparedness more clearly than do we, with all that it connotes of internal readiness. It is only within the last few years that the old-time industrial departments of railroads, which were great in the same manner as are balloons, have been modernized by the addition of serious-minded scientists equipped with the indispensable industrial research laboratories, as the sciences upon which success must be based are so interdependent that a specialist in one of them is not of much value unless he has at least enough knowledge of the others to know when he is getting beyond his depth in them. But the immediate and crying need of our chemical industries is research of the business order and they have such limitless possibilities that it is clear beyond any one to venture prophecy as to what they may become.

So far in our endeavors we realize that we have but "scratched the surface." The underlying idea is that particular idea upon which most of our great industries have been based-that of service; and, adapting our views and wishes of what should be done to our abilities to perform it, we have made up our minds and have told a few people who have already come to us for advice and assistance, that if there was anything in America at which we could get there was no trip too long for us to send a properly qualified man to get the information that might be at the end of the road to put at the disposal of our client.

There was a time in our history when if you went to a banker for a loan for which you wished to hypothecate securities, he seemed to figure as to how he would get your securities for the least possible percentage of their value, but no legitimate banker does such things as that now.

By the same token there may have been times in the past when the railroads did business on some such piratical hypothesis, but that day is over and most of us who represent the younger generation of railroad men are inclined to deny rather vehemently the existence of these old-time rules of the "biggest gun" because we have only a little hearsay but no knowledge of how they were worked.

At the first chemical exposition, held within a year after the war began, in 1915, and attended by over 60,000 people, there were no railroads; at the second, which more than doubled the first in most ways and was attended by nearly 80,000 , there was one; this year if you look around you will find five; and while we all have recognized within the last few years the utter futility of prophecy it would not surprise me greatly if the geometrical ratio between these numbers be carried into the progression which will be shown by the number of those you will see in 1918 , because few things, if indeed any, have done more toward broadening and quickening the advancement of industrial chemistry or to bring to all of the different industries that go to make up our business life greater realization of the benefits accruing from properly directed chemico-industrial engineering and research.

There isn't a productive industry shown in this great exhibit, of whose unusual value for publicity, education and business acquaintance every live manufacturer should avail himself, that is not absolutely dependent upon some kind of original raw material coming from the earth and very few of them are of any value until they have been assembled with others-transported in some way to a central point where they went through the various processes we call "manufacturing" to some useful form.

New discoveries which industrial chemistry is continually performing are the basis of the increasing tendency to develop low-grade properties. Many places in the country are working over their old dumps and making more money than did the orig- inal property. It does not take much of a mathematician to see the effect of this because the freight on a car of 45 per cent ore is about the same as the freight on a car of 75 per cent ore; hence it is inevitable that such plants will go to the source of their raw material and it is apparent that the railroad which knows the most about the mineral deposits in its territory is going to be the strongest contender when it comes to locating them.

After the lesson of the last three years no real American disputes the importance of making ourselves independent of all other countries. I think I am safe in making the assertion that twenty-five years ago the whole railroad industry in America did not have ten chemists in its regular employ: nowadays a railroad that does not have a sufficient number of well-trained chemists to do its work is a "back number," whether it knows it or not, and the field of the chemists on railroads has just begun to open as railroading is also becoming a science whose operation uses more than half the known elements. The chemist's first efforts seem to have been destructive although he did not so intend, but in the future, while his critical field will continue to expand, his greatest use will be in the way of aiding the industries to do better instead of sitting by to tell them how bad their products really are.

The South that was practically left for dead something over a generation since is coming into a life of which few of its citizens in the past even dreamed and we are expecting to be among those present at the profit-taking. The resurrection of the South is a real thing. The value of our cotton crop this year will just about equal the value of all of the gold that the State of California has produced in the best fifty years of its history.

A few years ago there were only a few Southern textile mills; a few years earlier than that there weren't any. But they took approximately 55 per cent of the 1915 crop; they took about 60 per cent of the 1916 crop. The precentage they require of the present crop will be still higher.

The number of industrial and developmental projects that were inaugurated in the South during the first half of this year is simply astonishing. The statement in the Manufacturers Record shortly after the close of the first six months lists more than twenty-seven thousand $(27, I 67)$ and, strange to say, this number does not exceed that of the corresponding period of $19 \mathrm{I} 6$ but it does represent a great deal more money as these ventures involved sums of money all the way from a few thousand up to, in one case, fifty million, and when I tell you that the projector of the fifty-million-dollar enterprise was the Bethlehern Steel Company you are at liberty to decide for yourselves as to whether or not it will be put through. These great industries are being established in the South as permanent ones and the communities which are successful in securing chemical industries in the beginning are the ones that are going to become their great centers.

\section{BUILDING A COMPLETE CYCLE OF CHEMICAL INDUSTRIES} ON THE CLINCHFIELD

EXTRACTS FROM ADDRESS $\mathrm{BY}$ VICTOR V. KELSEY

Chemist-Industrial Agent, Carolina, Clinchfeld and Ohio Railway

The Carolina, Clinchfield and Ohio Railway, frequently spoken of as "The Clinchfield," traverses a portion of Southeastern Kentucky, Southwestern Virginia, Eastern Tennessee, Western North Carolina and South Carolina. The mining, manufacturing and distributing plants located along the Clinchield enjoy a central and strategic location in reference to the domestic trade of the more populous sections of the United States The Clinchfield territory presents superior features both from the standpoint of assembling raw materials and the distribution of finished products.

One of the prime considerations that led to the construction of the Clinchfield was the opportunity it afforded to unlock the immense storehouse of power, other minerals and the virgin timber. The coal fields made available by the Clinchfield are 